Ambiente \& Água - An Interdisciplinary Journal of Applied Science
ISSN 1980-993X - doi:10.4136/1980-993X
www.ambi-agua.net
E-mail: ambi.agua@gmail.com

\title{
Evaluation of the effects of bio stabilised waste on soil in terms of heavy metal accumulation and leaching ${ }^{1}$
}

\author{
ARTICLES doi:10.4136/ambi-agua.2228
}

Received: 09 Jan. 2018; Accepted: 28 Feb. 2018

\author{
Francesco Lombardi*; Giulia Costa; Maria Chiara Di Lonardo; Alessio Lieto \\ Università degli Studi di Roma Tor Vergata, Rome, Italy \\ Department of Civil Engineering and Computer Science Engineering \\ E-mail: lombardi@ing.uniroma2.it,costa@ing.uniroma2.it,di.lonardo@ing.uniroma2.it, \\ lieto@ing.uniroma2.it \\ *Corresponding author
}

\begin{abstract}
This work evaluated and compared potential impacts related to the accumulation and/or release of heavy metals resulting from the application of different types of stabilized waste to soil. Namely, the following three types of flows were considered: waste produced by aerobic bio-stabilization of municipal solid waste at a Mechanical Biological Treatment (MBT) plant, and compost produced either from aerobic composting or from a combination of anaerobic and aerobic biodegradation processes. After a preliminary characterization of the materials (organic matter content, volatile solid, and heavy metals content), heavy metal accumulation in soil caused by possible long-term application of these organic materials was evaluated by implementing a discretized mass balance based on the total content of the heavy metals in each type of solid matrix investigated. In addition, results of percolation leaching tests performed on each type of material were presented and discussed. Results highlight that although the total content of heavy metals of the three types of materials differed considerably, with the MBT waste presenting the highest concentrations, the results of the leaching percolation tests were quite similar.
\end{abstract}

Keywords: aerobic stabilization, anaerobic digestion, compost, leaching behavior, MBT waste, metal accumulation.

\footnotetext{
${ }^{1}$ A preliminary version of this article was published in the Proceedings of the 15 th International Conference of Environmental Science and Technology, Rhodes, Greece, 31 August to 2 September 2017. 


\section{Avaliação dos efeitos da aplicação de resíduos bioestabilizados no solo em termos de acumulação e lixiviação de metais pesados}

\section{RESUMO}

O objetivo do presente trabalho foi o de avaliar e comparar os potenciais impactos do acúmulo e/ou lançamento de metais pesados devido a utilização sobre o solo de diferentes matrizes de entulho urbano biodegradável depois da consolidação aeróbica. Em particular, foram consideradas as seguintes três matrizes de entulhos consolidados: Entulho produzido pela bioconsolidação aeróbica de entulhos sólidos urbanos depois do tratamento mecânico biológico, composto produzido de matriz selecionada de entulho sólido urbano depois da bioconsolidação aeróbica, composto produzido de matriz selecionada de entulho sólido urbano depois da bioconsolidação combinada anaeróbica e aeróbica. Os resultados obtidos evidenciam que o conteúdo dos metais pesados em cada uma das três matrizes pode variar consideravelmente registrando as maiores concentrações nas matrizes provenientes da bioconsolidação aeróbica de entulhos sólidos urbanos depois do tratamento mecânico biológico. No que diz respeito ao lançamento avaliado com o teste de percolação (lixiviação) as três matrizes se comportaram de modo simelhante.

Palavras-chave: acumulação de metal, comportamento de lixiviação, composto, digestão anaeróbica, estabilização aeróbica, resíduos de MBT.

\section{INTRODUCTION}

Recently the European Commission has been strongly promoting the enactment of a circular economic model aimed at preserving natural resources and minimizing landfill utilization. In this framework, Member States have taken actions to divert biodegradable municipal waste from landfills and to reduce impacts during their management due to their putrefying nature, with respect to both biogas and and leachate emissions. Specifically, two main strategies have been adopted for the management of this fraction aerobic and/or anaerobic biodegradation of the source-segregated Organic Fraction of Municipal Solid Waste (OFMSW), with production of compost and digestate, and mechanical-biological treatment (MBT) of residual MSW to produce bio stabilised waste, besides waste-derived fuels aimed at energy recovery (Abdullahi et al., 2008; Di Lonardo et al., 2016). Compost is generally used in agriculture as a fertilizer and for improving the soil's physical and chemical properties (Westerman and Bicudo, 2005; Hargreaves et al., 2008). Northern European countries such as Denmark, Sweden or Germany admit the utilization of digestate as a soil fertilizer (Möller and Stinner, 2009; Rodhe et al., 2006), but this activity is generally allowed only for the separately collected organic fraction of MSW. Differently, the main fate of MBT waste is landfilling due to its higher content of non-biodegradable materials (e.g. plastic pieces) and heavy metals compared to compost (Di Lonardo et al., 2012). However, the interest in the possibility of recovering MBT waste is increasing (MacLeod et al., 2008), especially considering the large amounts that are being produced in efforts to divert waste from landfills (Farrell and Jones, 2010; Pantini et al., 2015a; 2015b). One of the possible ways to recover MBT waste is as landfill cover material for promoting vegetation growth (Angermeier et al., 2010); application to degraded and/or contaminated soils of these organic rich fractions has been also proposed (Farrell and Jones, 2010). To date Italy has a specific regulation for the reuse of bio stabilised fractions like compost as soil improvers (D.Lgs. 217/06). Requirements are expressed in terms of total composition (e.g. total content of heavy metals), not leaching behaviour. It is, however, well established that the potential risks to the environment related to the use or disposal of a 
material should be assessed also in terms of release when in contact with water, not only total content (van der Sloot et al., 2003).

This study was aimed at assessing and comparing the application on soil of different types of treated bio-waste produced from a Mechanical Biological Treatment plant, an aerobic composting process and from a combination of anaerobic and aerobic biodegradation processes (Pantini et al., 2015a; Di Gianfilippo et al. 2016a; 2016b). To this aim, metal accumulation caused by the long-term application of bio-stabilized waste on soil was assessed by implementing an approach based on a discretised mass balance over time as suggested by the European Compost Network (ECN et al., 2015). In addition, leaching data from percolation tests (Pantini et al., 2015a; Di Gianfilippo et al., 2016a; 2016b) were analyzed in terms of heavy metal release over time.

\section{MATERIALS AND METHODS}

\subsection{Investigated samples}

Three different types of bio-stabilized waste materials were analyzed in this study: MBT waste (MTBW) produced by aerobic bio-stabilization of mechanically selected municipal waste, and two types of compost produced from an aerobic composting process (Compost A) and from a combination of anaerobic and aerobic biodegradation processes (Compost B).

The MBT waste was sampled in a plant that has a maximum treatment capacity of $750 \mathrm{Mg}$ $\mathrm{MSW} / \mathrm{d}$. Downstream from a primary mechanical sieving unit at $90 \mathrm{~mm}$, electromagnetic separators remove metals and the biodegradable fraction is sent to a bio-stabilization basin, where forced aeration conditions enhance the aerobic biodegradation of the organic fraction. After around 28 days, the output is mechanically sieved at $20 \mathrm{~mm}$ in order to separate the oversize fraction enriched in plastics and inert materials (Di Lonardo et al., 2015).

The Compost A sample was collected from a plant that treats source-segregated organic fractions of MSW (from local markets, restaurants and households) with a maximum treatment capacity of $82 \mathrm{Mg} / \mathrm{d}$. After 28 days at forced aeration conditions, the material was subjected to a ripening stage at natural aeration conditions for 180 days and then sieved at $10 \mathrm{~mm}$.

The Compost B sample was collected from a biodigestor/composting plant which likewise treats source-segregated organic fractions of MSW (mainly food and green waste) with a maximum treatment capacity of $120 \mathrm{Mg} / \mathrm{d}$. This plant is made up of two different biodegradation processing stages. First, an anaerobic digestion stage lasting 15 days is carried out for a part of the input waste; the digestate output is then mixed with the remaining waste and sent to the aerobic composting stage. Downstream from a mechanical sieving unit at $40 \mathrm{~mm}$, the organic fraction remains in bio-cells at forced aeration conditions for 20 days. The bio-stabilized material is kept at natural aeration conditions for 90 days in order to achieve ripening conditions. Secondary mechanical sieving at $10 \mathrm{~mm}$ is carried out at the end of the ripening phase. The oversize flows are recirculated at the beginning of the process in order to act as structuring materials during the two biodegradation stages.

\subsection{Evaluation of metals accumulation in topsoil}

Bio-stabilized materials do not contain only nutrients and organic matter, but also a significant quantity of minerals and specifically metal bearing phases. While the organic matter fraction can be mineralized and the nutrients absorbed by plants, the mineral fraction remains permanently, contributing to soil structure. Therefore, mineral components, which remain in the soil over time, cause an increase in soil horizon and contribute in defining its contamination level. In order to evaluate the effect of pollutants accumulation in topsoil resulting from the application of bio-stabilized materials on one hectare of soil, the model presented by the European Compost Network for compost was used (ECN et al., 2015). Specifically, the 
following equation was considered (Equation 1):

$C_{B o_{-} t}=\frac{\left(C_{S a m p} * M * 0.1 * t\right)+\left(C_{B o} * d * 1000 * h\right)}{(d * 1000 * h)+\left(M * A_{l o n g} * 0.1 * t\right)}$

Where:

t: Period of application (years)

$\mathrm{C}_{\mathrm{Bo}}$ : Metal concentration in relevant soil horizon $(\mathrm{mg} / \mathrm{kgTS})$

$\mathrm{C}_{\text {Bo_- }}$ : Metal concentration in relevant soil horizon after $\mathrm{t}$ years $(\mathrm{mg} / \mathrm{kgTS})$

$\mathrm{C}_{\text {Samp }}$ : Metal concentration in the compost $(\mathrm{mg} / \mathrm{kgTS})$

h: Soil horizon thickness (m)

M: Annual application rate (MgTS/ha)

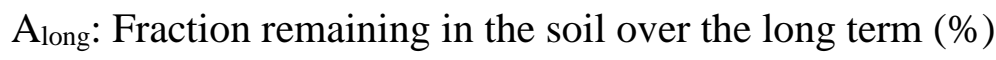

$\mathrm{d}$ : Dry bulk density of soil $\left(\mathrm{g} / \mathrm{cm}^{3}\right)$

In the mass balance (Equation 1) a soil, with a horizon thickness $h$ of $30 \mathrm{~cm}$ and a dry bulk density $d$ of $1.7 \mathrm{~g} / \mathrm{cm}^{3}$ was considered (ECN et al., 2015). We assumed an application on soil of $10 \mathrm{Mg}$ (ha* year) of dry matter of bio-stabilized waste for a period of $t$ consecutive years. The application rate $M$ corresponds to the maximum value allowable for compost in Germany, assumed also in the ECN study (ECN et al., 2015). In order to take into account of the longterm application of the materials to soil, it should be considered that stable fractions contribute to long-term soil structure. In this study, the fraction remaining after long-term application ( $A_{\text {long }}$ ) was assumed to be equal to the mineral fraction of the material plus the portion resistant to biological degradation. The former was assumed to be equal to $82.5 \%$ of the ash content, while the latter was estimated by assuming that $26 \%$ of the organic matter, expressed as VS, contained in the bio-stabilized waste remains in the soil over the long term (Deller et al., 2008). $C_{B o}$ and $C_{S a m p}$ represent the initial metal concentrations in soil and in the bio-stabilized waste respectively, whereas $C_{B o_{-} t}$ corresponds to the concentration in the soil horizon after t years of application of the bio stabilised materials.

\subsection{Leaching behavior}

In our previous studies, we specifically investigated the leaching behavior of the waste materials considered in this work (Pantini et al., 2015a), as shown in Table 1, where the contents of organic matter (volatile solids and total organic carbon) and heavy metals are also reported.

Table 1. Results (mean \pm standard deviation) of the samples' characterization (partially, Pantini et al., 2015a).

\begin{tabular}{lcccccc}
\hline \multirow{2}{*}{ Parameters } & \multicolumn{3}{c}{ Solid content } & \multicolumn{3}{c}{ Eluates from column test (L/S =10) } \\
\cline { 2 - 7 } & MBTW & Compost A & Compost B & MBTW & Compost A & Compost B \\
\hline Ash (\%) & $45.8 \pm 1.6$ & $32.7 \pm 0.7$ & $47.6 \pm 0.3$ & - & - & - \\
VS (\%) & $54.2 \pm 1.6$ & $67.3 \pm 0.7$ & $52.4 \pm 0.3$ & - & - & - \\
TOC (\%) & $27.0 \pm 0.5$ & $25.2 \pm 0.8$ & $21.8 \pm 0.4$ & - & - & - \\
Cu (mg/kgTS) & $172 \pm 110$ & $57.2 \pm 2.1$ & $79.3 \pm 4.5$ & $0.11 \pm 0.012$ & $0.45 \pm 0.001$ & $0.12 \pm 0.004$ \\
Ni (mg/kgTS) & $15.7 \pm 0.4$ & $16.3 \pm 2.0$ & $12.3 \pm 1.0$ & $0.09 \pm 0.058$ & $0.20 \pm 0.001$ & $0.10 \pm 0.001$ \\
Pb (mg/kgTS) & $350 \pm 120$ & $25.9 \pm 0.7$ & $41.0 \pm 0.1$ & $0.41 \pm 0.023$ & $0.19 \pm 0.003$ & $0.14 \pm 0.001$ \\
Zn (mg/kgTS) & $370 \pm 7$ & $164.4 \pm 3.1$ & $350.8 \pm 22.4$ & $0.16 \pm 0.051$ & $6.62 \pm 0.101$ & $0.06 \pm 0.055$ \\
\hline
\end{tabular}


Although the three samples proved quite different, especially in terms of heavy metal contents, an interesting finding was that the metals leaching kinetics as a function of the L/S ratio seemed to be governed by the same mechanisms (Pantini et al., 2015a). To evaluate how much water could come in contact with the material in the application area, the empirical model proposed by Connor et al. (1997), which allows one to estimate the net infiltration rate as a function of the average annual rainfall $P(\mathrm{~cm} /$ year) and of the predominant soil type (sand, silt or clay), was used (Equation 2 for silty soil). The net infiltration rate $I_{f}$ was utilized to estimate, for the application area $A$, how much water could infiltrate into the soil after every year (Equation 3) and how long it takes to pass through the soil horizon thickness (Equation 4).

$I_{f}=0.0009 *(P)^{2}$

$Q_{\text {inf }}=I_{f} * A * 10$

$t_{\text {inf }}=h / I_{f}$

Where:

If: Net infiltration rate ( $\mathrm{cm} /$ years)

A: Area of infiltration $\left(\mathrm{m}^{2}\right)$

Qinf: Water that infiltrates in area $A$ (1/year)

tinf: Time to pass through $h$ (years)

The net infiltration $I_{f}$ was evaluated by considering an annual precipitation value $P$ of $77.2 \mathrm{~cm} /$ year, assumed by the European average rainfall in 2008 (http://www.nationmaster.com).

This value was used to calculate how much time the topsoil, represented by the first $30 \mathrm{~cm}$ of soil and the accumulated bio stabilised material, need to come in contact with rainfall to reach the investigated liquid to solid ratios adopted in the percolation tests (Table 2).

Table 2. Time to reach the investigated $\mathrm{L} / \mathrm{S}$ assuming to apply $1 \mathrm{~kg}$ of material to $1 \mathrm{~m}^{2}$ of soil (Average annual rainfall $P=77.2$ $\mathrm{cm} /$ year; predominant soil type: Silt; horizon thickness $h=30 \mathrm{~cm}$ ).

\begin{tabular}{lccccc}
\hline Years & 0.21 & 0.42 & 0.63 & 0.84 & 1.05 \\
\hline $\mathbf{L} / \mathbf{S}(\mathbf{l} / \mathbf{k g})$ & 2 & 4 & 6 & 8 & 10 \\
\hline
\end{tabular}

\section{RESULTS AND DISCUSSION}

\subsection{Metals accumulation in soil}

Figure 1 shows how the concentration in the relevant soil horizon changes over time.

Since nutrient uptake by plants is not considered in this work, the $A_{\text {long }}$ values were found to be equal to $51.9 \%$ for MBT W, $44.5 \%$ for Compost A and $51.4 \%$ for Compost B, therefore the materials were considered to lose approximately half of their initial weight.

In order to evaluate how bio-stabilized materials contribute to the accumulation of heavy metals in soil, the initial concentration in the relevant soil horizon $C_{B o_{-} t}$ was considered to be null. Results show an increasing trend of heavy metal concentration in soil, which is strongly 
influenced by the type of material considered. Metals with a similar concentration value show a similar trend, like Ni in all the three investigated samples. MBTW trends confirm that aerobic bio-stabilization of mechanically selected municipal waste produces a material with a higher metal content which may theoretically lead to exceed the threshold values for reuse in residential sites, but only for very long application timeframes (i.e. 175 years for $\mathrm{Pb}$ ). In 50 years, the total metal content would appear not to exceed the Italian soil contamination threshold values for residential use (Italian Decree N 152, 2006). Figure 2 shows how the initial concentration of a metal in the soil horizon can influence the results, with $\mathrm{Cu}$ as an example.
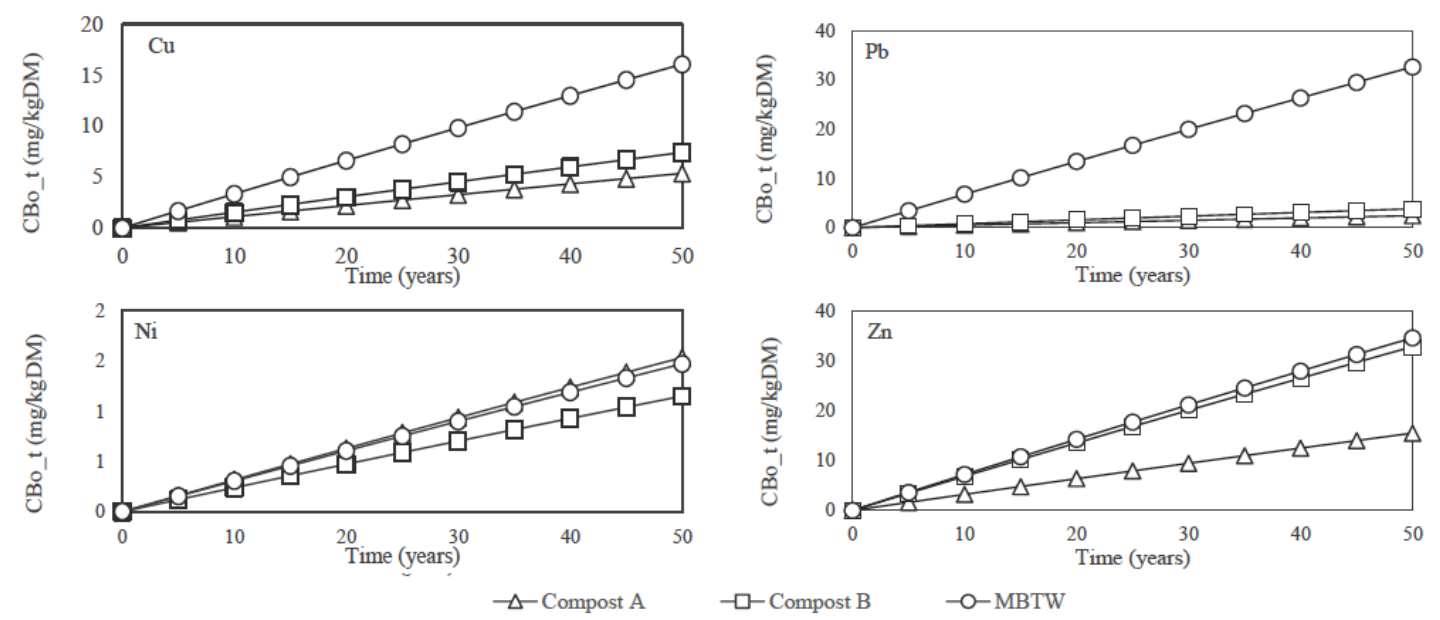

Italian soil contamination thresholds in mg/kgTS: $\mathrm{Cu}=120 ; \mathrm{Ni}=120 ; \mathrm{Pb}=100 ; \mathrm{Zn}=50$

Figure 1. Metal accumulation in the soil over the time.

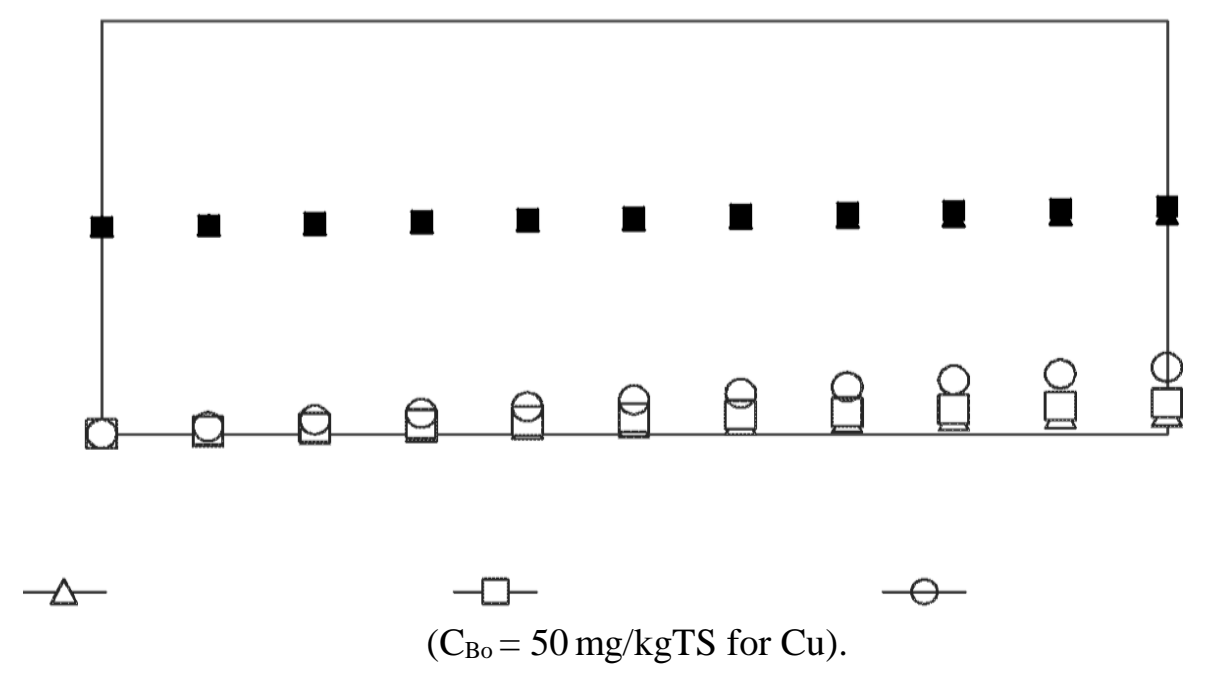

Figure 2. Metal accumulation in the soil over the long term, at different initial concentration values.

Taking into account the mass balance of the initial metal content in the soil results in an increase of the metal concentration in the relevant soil horizon, but also in a slightly slower increase of metal accumulation over time. It is important to highlight that Equation 1 can be used to estimate the maximum value of concentration in the relevant soil horizon for $t \rightarrow \infty$ (Equation 5).

$C_{B o_{-} t} \cong \frac{\left(C_{\text {Samp }} * M * 0.1 * t\right)}{\left(M * A_{\text {long }} * 0.1 * t\right)}=\frac{C_{\text {Samp }}}{A_{\text {long }}}$ for $t \rightarrow \infty$ 
The maximum value of concentration in soil depends only on $A_{\text {long }}$; meaning that concentrations approximately double for $\mathrm{t} \rightarrow \infty$.

$$
\begin{array}{ll}
C_{B o_{-} \infty} \cong 1 / 0.519 C_{\text {Samp }}=1.93 C_{\text {Samp }} & \text { for MBTW } \\
C_{B o_{-} \infty} \cong 1 / 0.445 C_{\text {Samp }}=2.25 C_{\text {Samp }} & \text { for Compost } A \\
C_{B o_{-} \infty} \cong 1 / 0.514 C_{\text {Samp }}=1.95 C_{\text {Samp }} & \text { for Compost } B
\end{array}
$$

It should be noted that metal accumulation calculated on the basis of Equation 1 should be considered as a first conservative estimate, since owing to rainwater infiltration in the soil layer, metals, salts and other constituents are gradually leached from the bio stabilised materials, which determines a decrease over time of their total content in the amended soil.

\subsection{Leaching behavior}

Figure 3 shows the results of dynamic column percolation tests obtained in previous studies (Pantini et al., 2015a). Metal concentrations in the leachate, expressed in (mg/l) as a function of the L/S ratio, tend to gradually decrease for an increase of the amount of water that infiltrates through the material.

As can be noted, notwithstanding the different initial content of potential contaminants in the three types of bio stabilised materials, their leaching trends as a function of the L/S ratio were quite similar (see e.g. the leaching curves resulting for $\mathrm{Pb}$ ). However, also in this case the highest concentrations were generally retrieved in the leachate of the MBT waste, especially at low L/S ratios. Table 2 shows the time, calculated through Equation 4, needed to reach the L/S of the percolation tests, assuming the application of $1 \mathrm{~kg}$ of material to $1 \mathrm{~m}^{2}$ of soil. As can be noted, for the assumed conditions the resulting infiltration rate leads to achieve a $\mathrm{L} / \mathrm{S}$ of $10 \mathrm{l} / \mathrm{kg}$ in just over a year.
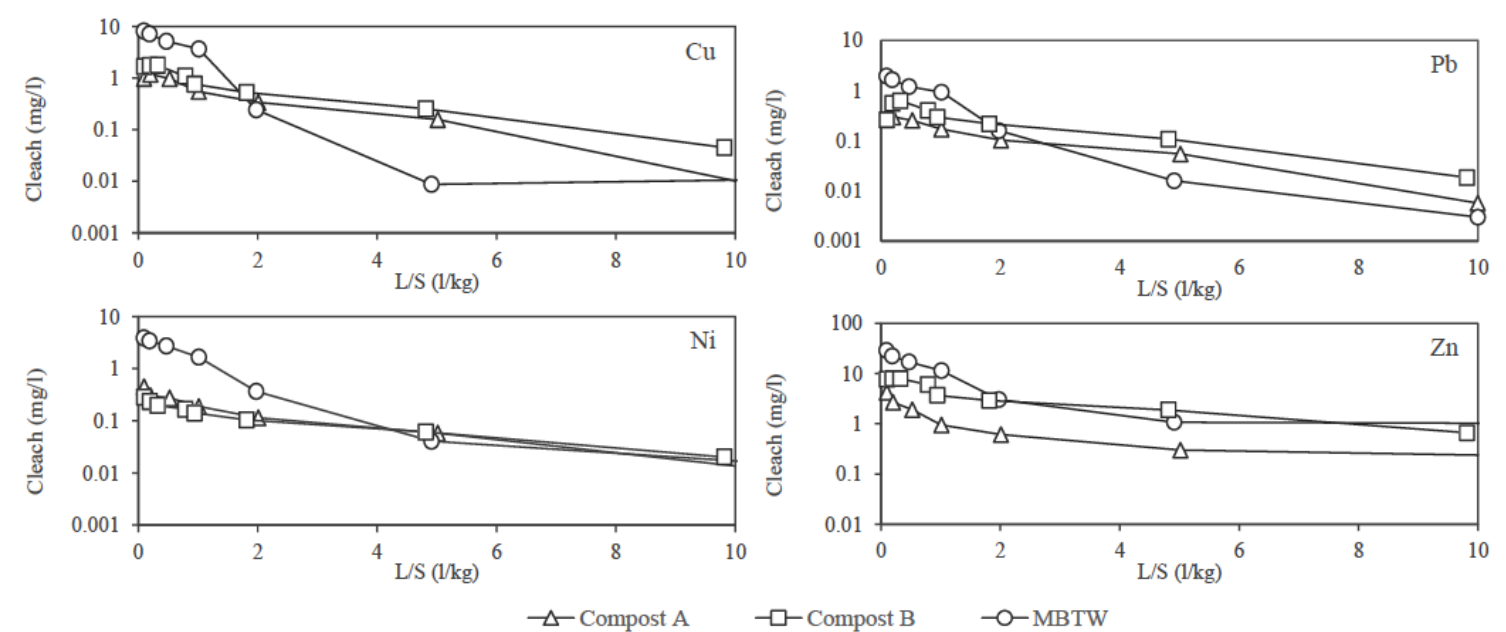

Figure 3. Metal release in solution, resulting from percolation leaching tests.

\section{CONCLUSIONS}

The results of this preliminary study indicate that heavy metal concentrations may progressively increase in soils due to the application of bio stabilised materials. The total metal content strongly influences pollutants' accumulation in soil, but it is only one of the factors influencing potential contamination. In fact, organic matter can modify the soil structure, especially considering the degradation that characterises this fraction during the long term. In addition, it should be considered that metals may be released over time due to leaching upon 
contact with rainwater or uptake by vegetation. The mobility of potential contaminants is influenced by the nature of the bio-stabilized waste, but may also depend upon the characteristics of the soil to which they are added and the intensity of the annual precipitation on the investigated area. Future studies will address the modification of the model employed in this work for the evaluation of metal accumulation in soils amended with bio stabilised materials in order to possibly take the above-mentioned phenomena (leaching in particular) into account and to also assess the potential impacts of bio stabilised materials on groundwater quality when applied to soil.

\section{REFERENCES}

ABDUlLAHI, Y. A.; AKUNNA, J. C.; WHITE, N. A.; HALLETT, P. D.; WHEATLEY, R. Investigating the effects of anaerobic and aerobic post-treatment on quality and stability of organic fraction of municipal solid waste as soil amendment. Bioresource Technology, v. 99, p. 8631-8636, 2008. https://doi.org/10.1016/j.biortech.2008.04.027

ANGERMEIER, R.; TINTNER, J.; SMIDT, E.; OTTNER, R.; MATIASCH, L.; BINNER, E. et al. Development of mechanically biologically treated municipal solid waste under different vegetation types. Journal of Environmental Engineering, v. 137, n. 5, p. 340346, 2010. http://dx.doi.org//10.1061/(ASCE)EE.1943-7870.0000336

CONNOR, J. A;, BOWERS, R. L.; PAQUETTE, S. M.; NEWELL, C. J. Soil attenuation model for derivation of risk-based soil remediation standards. Groundwater Services Inc., Houston, Texas, p. 1-34. 1997.

DELLER, B.; KLUGE, R.; MOKRY, M.; BOLDUAN, R.; TRENKLE, A. Effects of mid-term application of composts on agricultural soils in field trials of practical importance: Possible risks. Compost and digestate: sustainability, benefits, impacts for the environment and for plant production, v. 27, p. $29^{\text {th }}, 2008$.

DI GIANFILIPPO, M.; COSTA, G.; PANTINI, S.; LOMBARDI, F.; ALLEGRINI, E.; ASTRUP, F. T. LCA of management strategies for RDF incineration and gasification bottom ash based on experimental leaching data. Waste Management, v. 47, Part B, p. 285-298, 2016a. http://dx.doi.org/10.1016/j.wasman.2015.05.032

DI GIANFILIPPO, M.; COSTA, G.; VERGINELLI, I.; GAVASCI, R.; LOMBARDI, F. Analysis and interpretation of the leaching behaviour of waste thermal treatment bottom ash by batch and column tests. Waste Management, v. 56, p. 216-298, 2016b. http://dx.doi.org/10.1016/j.wasman.2016.07.034

DI LONARDO, M. C.; GAVASCI, R.; LOMBARDI, F. Characterization of MBT plants input and outputs: a review. In Reviews in environmental science and bio-technology, v. 11, p. 353-363, 2012. http://dx.doi.org/10.1007/s11157-012-9299-2

DI LONARDO, M. C.; BINNER, E.; LOMBARDI, F. Influence assessment of a lab-scale ripening process on the quality of mechanically-biologically treated MSW for possible $\begin{array}{llllll}\text { recovery. Waste } & \text { Management, } & \text { v. 43, }\end{array}$ http://dx.doi.org/10.1016/j.wasman.2015.05.028

DI LONARDO, M. C.; FRANZESE, M.; COSTA, G.; GAVASCI, R.; LOMBARDI, F. The application of SRF vs. RDF classification and specifications to the material flows of two mechanical-biological treatment plants of Rome: Comparison and implications. Waste $\begin{array}{lllllll}\text { Management, } & \text { v. } 47, \quad \text { Part } & \text { B, } & \text { p. }\end{array}$ http://dx.doi.org/10.1016/j.wasman.2015.07.018 
EUROPEAN COMPOST NETWORK - ECN. Calculation of contaminant accumulation in soil due to long term compost application. Bochum, 2015. p. 5-11.

FARRELL, M.; JONES, D. L. Use of composts in the remediation of heavy metal contaminated soil, Journal of Hazardous Materials, v. 175, n. 1, p. 575-582, 2010. https://doi.org/10.1016/j.jhazmat.2009.10.044

HARGREAVES, J. C.; ADL, M. S.; WARMAN, P. R. A review of the use of composted municipal solid waste in agriculture. Agriculture, Ecosystems \& Environment, v. 123, n. 1, p. 1-14, 2008. https://doi.org/10.1016/j.agee.2007.07.004

MACLEOD, I.; SAVAGE, A. L.; PAHL, O.; BAIRD, J. Decline in microbial activity does not necessarily indicate an end to biodegradation in MSW-biowaste: a case study. Bioresource technology, v. 99, n. 18, p. 8626-8630, 2008. https://doi.org/10.1016/j.biortech.2008.04.011

MÖLLER, K.; STINNER, W. Effects of different manuring systems with and without biogas digestion on soil mineral nitrogen content and on gaseous nitrogen losses. European Journal of Agronomy, v. 30, p. 1-16, 2009. https://doi.org/10.1016/j.eja.2008.06.003

PANTINI, S.; VERGINELLI, I.; LOMBARDI, F. Analysis and modelling of metals release from MBT wastes through batch and up-flow column tests. Waste Management, v. 38, p. 22-32, 2015a. http://dx.doi.org/10.1016/j.wasman.2014.12.002

PANTINI, S.; VERGINELLI, I.; LOMBARDI, F.; SCHEUTZ, C.; KJELDSEN, P. Assessment of biogas production from MBT waste under different operating conditions. Waste Management, v. 43, p. 37-49, 2015b. http://dx.doi.org/10.1016/j. wasman.2015b.06.019

RODHE, L.; SALOMON, E.; EDSTRÖM, M. Handling of digestates on farm level. Economic calculations. [S.1.]: JTI-rapport Landbruk \& Industry, 2006. p. 1401-4963.

VAN DER SLOOT, H. A.; COMANS, R. N. J.; MEEUSSEN, J. C. L.; DIJKSTRA, J. J. Leaching methods for soil, sludge and treated biowaste. Horizontal Desk study, v. 23, 2003.

WESTERMAN, P. W.; BICUDO, J. R. Management considerations for organic waste use in agriculture. Bioresource Technology, v. 96, n. 2, p. 215-221, 2005. https://doi.org/10.1016/j.biortech.2004.05.011 